DOI: $10.18287 / 2542-0445-2020-26-1-119-124$

УДК $8 ; 811.111$

Научная статья / Scientific article
Дата: поступления статьи / Submitted: 01.11.2019 после рецензирования / Revised: 14.01.2020 принятия статьи / Accepted: 21.02.2020

A.E. Fedotova

Lomonosov Moscow State University, Moscow, Russian Federation E-mail: fedot-nastya@inbox.ru. ORCID: http://orcid.org/0000-0003-2272-8337

\title{
Semantic transformations of maritime historicisms in modern English
}

\begin{abstract}
The article is dedicated to the study of English maritime historicisms in the modern English language. The author conducts research of English maritime historicisms aiming to prove that, firstly, they are actively used in modern English, secondly they changed their meanings and thirdly, their functions are not limited to the nominative one. Moreover, the author singles out numerous transformations that affect the meaning of maritime historicisms. The methods used by the author include: descriptive, comparative, systematizing methods and method of contextual analysis. The choice of maritime vocabulary as the material for analysis accounts for by two factors: 1) maritime affairs have always been closely associated with human activities of the British, hence, the English maritime vocabulary includes a large number of historicisms that were used to denote objects and events not existing now; 2) a considerable amount of written records where historicisms are used are still available, and on their basis maritime dictionaries which include historical terms have been compiled. The factual materials comprise numerous marine dictionaries, news columns, literary works, articles and encyclopedias. Conclusions reached by the author are as follows: English maritime historicisms form part of active vocabulary in the English language; four ways how they can change their meaning have been singled out and; apart from nominative function they perform expressive and evaluative functions as well. Theoretical and practical significance of the article consists not only in contributing to the knowledge about English maritime historicisms but also in tracing the association between Maritime History and its reflection in the English language. Moreover, the article can provide the basis for future research in discourse studies (e.g. studying the functional characteristics of historicisms in professional and non-professional communication) and terminological studies, translation of historicisms etc.
\end{abstract}

Key words: archaisms, historicisms, historical terms, extralinguistic factors, intralinguistic factors, active vocabulary, nominative function, metaphoric transfer of meaning.

Citation. Fedotova A.E. Semantic transformations of maritime historicisms in modern English. Vestnik Samarskogo universiteta. Istoriia, pedagogika, filologiia = Vestnik of Samara University. History, pedagogics, philology, 2020, vol. 26, no. 1, pp. 119-124. (In Russ.) DOI: http://doi.org/10.18287/2542-0445-2020-26-1-119-124.

Information on the conflict of interests: author declares no conflict of interest.

$\begin{aligned} \text { М.Е. Федотова } & \text { Фосковский государственный университет имени М.В. Ломоносова, г. Москва, Российская Федерация }\end{aligned}$ E-mail: fedot-nastya@inbox.ru. ORCID: http://orcid.org/0000-0003-2272-8337

\section{Трансформация значения морских историзмов в современном английском языке}

\begin{abstract}
Аннотация: Данная статья посвящена исследованию морских историзмов в современном английском языке. Традиционно морские историзмы рассматриваются как пласт пассивной лексики, нужный для обозначения реалий, неактуальных для современного мира. Автор проводит исследование морских историзмов английского языка и намеревается доказать, что: во-первых, они могут составлять пласт активной лексики; во-вторых, морские историзмы подвергаются различным трансформациям, из-за чего изменяют свое значение; в-третьих, помимо номинативной функции морские историзмы могут выполнять другие функции. Методы, используемые автором, включают в себя описательный, сопоставительный, систематизирующий, а также метод контекстного анализа. Выбор морской лексики в качестве анализируемого материала не случайно обусловлен двумя факторами: 1) морское дело всегда имело тесное отношение к жизни общества, следовательно, морская лексика включает в себя огромное количество историзмов; 2) до наших дней дошло значительное количество документов, фиксирующих употребление историзмов, на основе которых были составлены словари морской лексики, фиксирующие исторические термины. Список материалов включает в себя словари морской лексики, произведения художественной литературы, энциклопедические сводки и статьи новостного и образовательного характера. Автор статьи приходит к следующим выводам: доказано, что морские историзмы в английском языке могут входить в состав активной лексики; выделено четыре трансформации, влияющие на значение морских историзмов; анализ контекстуального употребления морских историзмов показал, что помимо номинативной функции историзмы выполняют также экспрессивную и оценочную функцию. Статья обладает как теоретической, так и практической значимостью, которая не только состоит в возможности усовершенствовать знание о морских историзмах английского языка, но и помогает проследить связь между историей и ее отражением в языке. Помимо этого, статья закладывает основы для будущих исследований в области терминологии и дискурсивного анализа. Перспективными вопросами для исследования являются перевод исторических терминов, а также функционирование историзмов в различных текстах как официального, так и неофициального дискурса.
\end{abstract}

Ключевые слова: архаизмы, историзмы, исторические термины, экстралингвистические факторы, интралингвистические факторы, активная лексика, номинативная функция, метафорический перенос значения. Цитирование. Fedotova A.E. Semantic transformations of maritime historicisms in modern English // Bестник Самарского университета. История, педагогика, филология. 2020. T. 26. № 1. С. 119-124. DOI: http://doi. org/10.18287/2542-0445-2020-26-1-119-124.

Информация о конфликте интересов: автор заявляет об отсутствии конфликта интересов. 


\section{ИНФОРМАЦИЯ ОБ АВТОРЕ / INFORMATION ABOUT THE AUTHOR}

(C) Анастасия Евгеньевна Федотова - аспирант филологического факультета, Московский государственный университет имени М.В. Ломоносова, 11991, Российская Федерация, г. Москва, Ленинские горы, 1.

\section{Introduction}

According to traditional approach historicisms are regarded as "words which denote things that are no longer used (names of social relations, institutions, objects of material culture of the past)" [Elena Kruglikova 2016, p. 145] or "words that belong to passive vocabulary and unlike archaisms do not have synonyms in active vocabulary" (Dictionary of modern Russian literary language 1965, p. 548). The above definitions make it possible to deduce the following characteristics of historicisms:

1) they denote the realia of the past which is not used in the modern language;

2) their function is mainly nominative;

3) they do not comprise the active part of the vocabulary;

4) they do not have synonyms.

The article seeks to prove that numerous historicisms not only form part of the active English vocabulary but they may change their meaning within its frames. Having undergone such changes, they are no longer associated with the object of the past. It should be pointed out that certain scholars have already paid attention to this fact by conducting analysis of historicisms in Spanish and German. Thus, L.A. Lazutova proved that historicisms in modern German not only can actively be used but they may perform evaluative and stylistic functions (Lazutova 2005).

The author attempts to prove that the above mentioned conclusions are legitimate in case of English and moreover the comparison of original and modern historicisms in different English contexts shows that they usually change their meaning .

1. Archaisms, historicisms and historical terms

The problem of archaisation has been in the focus of studies conducted by numerous Russian scholars, such as Y.S. Maslova, V.F. Belyanskaya, E.V. Kovaleva, A.V. Kalinin, S.I. Ozhegov, L.N. Shmelev, E.G. Mikhailova and others. However, despite their efforts no single approach to streamline between different groups of archaic words has been worked out.

The traditional approach to distinguishing historicisms and archaisms is regulated by both intralinguistic and extralinguistic factors. The first one presupposes that the word is replaced by its synonyms that are more suitable to modern English. The second one deals with the cases when a word out of use because the object it denotes became an anachronism, and thus there is no reason for the word to be a part of the active vocabulary. In the first case we deal with archaisms, in the second - with historicisms [Kolesnik 1977, p. 54].
(C) Anastasiya E. Fedotova - postgraduate student, Faculty of Philology, Lomonosov Moscow State University, 1, Leninskie Gory, Moscow, 119991, Russian Federation.

Nevertheless certain scholars do not support this point of view and state that archaic words cannot be classified according to the above-mentioned criterion, as both archaisms and historicisms can go out of use due only to extra linguistic reasons (Kovaleva 1996, p. 13). N.M. Shansky writes "to identify the exact reasons why words of the active vocabulary become archaisms and are replaced by other words is quite a tough task" [Shansky 2013, p. 148]. Moreover, numerous scholars (B.N. Golovin and V.N. Klyueva) claim that historicisms form a subcategory of archaisms and cannot be regarded as an individual group, while such scholars as O.S. Akhmanova and A.I. Smirnitsky do not single out this category at all.

The author of the article under consideration advocates the traditional approach and supports the view that the key difference between historicisms and archaisms lies in the so-called 'chronological information'[Kodukhov 1979, p. 8]. The chronological information of historicisms is the information about the development of the society, whereas the chronological information of archaisms is that one about the development of language.

It should be mentioned that some scholars (Edneralova 2003) [Brandes 2011] divide historicisms into two categories. The first one includes historical terms, i.e. historicisms that denote objects of the past which are no longer used but which had a great impact on the nation's history and on thedevelopmentofculture. Thesecondcategoryconsists of non-terminological historicisms, i. e. historicisms that denote everyday objects and notions. However this approach is not widespread and traditionally historicisms are classified either on the basis of the sphere to which objects they denote belong or on the basis of historical epoch they refer to (Konchakova 2008; Hajnzhamc 2007). This article regards maritime historicisms as a wider group which includes both historical maritime terms and non-terminological marine historicisms.

\section{Transformation of meaning maritime historicisms \\ Metaphorisation}

The first transformation under consideration is metaphorisation which involves introduction of the elements of the well-known reality to the new notion, which are reflected in the new metaphoric meaning closely connected with the world image reflected in language [Telia 1988, p. 186].

The first example of this process is admiral of the white and admiral of the red. Both terms were coined in the $17^{\text {th }}$ century when Royal Navy was divided into three squadrons, which had their unique colours the Van, identified by white ensigns, the Centre, 
with red ensigns, and the Rear, with blue ensigns correspondingly. Admiral was in command of each squadron and thus were referred to as admiral of the white (squadron), admiral of the red (squadron) and admiral of the blue (squadron). However the set terms were involved into the metaphorisation process and gained some additional meanings, thus admiral of the white stands for "a white-face person, a coward" (used mainly when describing a coward on board) (Simpson 1973, 28 p.) and admiral of the red means "a wine-bibber" (used to describe drunkard sailors) (Simpson 1973, p. 28). It should be noted that both terms having undergone metaphorisation gained pejorative connotations and thus perform not only nominative but expressive and evaluative functions as well.

Another example is Blue Monday. Historically this term used to mean "the day when sailors on the English ships who committed certain offences during the week were punished" (Skryagin, Kalanov 2013, p. 40). This day was called Blue Monday to refer to the bruises left after the beats left by the so-called cat o'nine tails (often shortened to cat) - "similar to a whip, an instrument of punishment where seamen were flogged on their bare backs" (Marine Terms Dictionary, online resource).Thus, initially this term was based on metonymic transfer of meaning. However in 2005 this term gained another meaning "the most depressing day of the year" (Burnett 2012, online resource). Such meaning was coined by $\mathrm{Dr}$ Cliff Arnell who later confessed that his initial aim was "to inspire people to take action and make bold life decisions rather than emphasizing misery of year's joyless date" (Peat 2018, online resource). Modern English dictionaries define this term as "a Monday that is depressing or tiring especially because of the return to work and routine after a weekend" (Merriam-Webster Dictionary, online resource). The word component blue no longer refers to bruises, but is connected with sadness or depression. Thus, here we are faced with the situation when a historicism underwent changes and by means of metaphorisation gained another meaning. Not only did the term itself change but its functions changed as well. First of all the expression gained pejorative connotations and thus it performs not only nominative function but evaluative as well.

A demonstrative example is Nelson's touch (or the Nelson touch). Initially this phrase was introduced by Nelson himself in summer 1805 when he told Lord Sidmouth about his ideas for his next battle on the sea. He named this collection of ideas The Nelson Touch [White 2002, p. 236]. When Nelson died this name turned into a term defining his leadership style and battle plans, but now it refers to the "masterly or sympathetic approach to a problem" (Lexico English Dictionary, online resource). As for the functions performed in modern English Nelson's touch now performs evaluative function, see the following context:

Hoffman, reviewing the situation nearly a century later, concluded that "the real deficiency, however, was the loss of Nelson's touch" (Foss, Saebi 2015, p. 38).
The Netherlands objected on both of the two last grounds, but did not specify any legal consequences. In contrast, Spain did not object, but interpreted the reservation to mean that legislation or other action by the Unites States would continue to be in accordance with the convention. This had more of the Nelson touch (Aust 2013, p. 132)

A really demonstrative example is the term sheet anchor. Historically it defined the "heaviest anchor of a large vessel, shipped in a ready position to be used for any emergency. In the later years of large sailing ships, this was the third bower and was usually carried in the starboard bow next to the best bower" (Steffy 2013, p. 1108). In modern English this historical term by means of metaphorisation gained another meaning - "something that constitutes a main support or dependence especially in danger" (Merriam-Webster Dictionary, online resource). This meaning is expressive and has definitely ameliorative connotation, see the contexts:

Firstly as we highlighted the 50 per cent retracement of the recent up move which coincides with the '20-SMA'on daily chart and more importantly, the previous breakout zone of 11,200 - 11,100, which now ideally should act as a sheet anchor support for the Nifty (Chavan 2019, online resource).

I recognize the Republican party as the sheet anchor of the colored man's political hopes and the ark of his safety (Anchor Quotes, online resource).

\section{Idiomisation}

Another transformation to regard is when term forms an idiom. In such cases the connection with historical background is virtually lost.

The first example to adduce in this category is the term cat. Historically it had a longer form cat o'nine tails and defined "a whip, first with three, then with six, and lastly with nine lashes, used for punishing offenders, and briefly called a cat" (Brewer 1898 , online resource). In the 17th century cat-o'nine-tails was used in the British army and navy but now this type of punishment it is no longer applied. Probably the punishment was first used on board ship, where ropes would be handy, and several ropes are called cats. Later this term formed such metaphors as not enough room to swing a cat - if you say There's no room to swing a cator You can't swing a cat, you mean that the place you are talking about is very small or crowded. Historically it meant "not enough space to punish a sailor using the cat o'nine tails". However, as it has been said the connection with the historical background is virtually lost and the idiom is no longer associate with navy. In modern English it mainly performs expressive function, which can be illustrated by the following contexts:

No room to swing a cat: What life might look like in one of Hong Kong's new 177sqft flats (South China Morning Post 2019, online resource).

He was perfectly charmed with his accommodation. Mrs. Crupp had indignantly assured him that there wasn't room to swing a cat there; but as $M r$. Dick Justly observed to me sitting down on the foot of 
the bed, nursing his leg, 'You know, Trotwood, I don't want to swing a cat. I never do swing a cat. Therefore, what does that signify to me!'(Dickens 1850, p. 743)

Another example ishistoricism brass monkey, which meant "a holder or storage rack in which cannon balls (or shot) were stacked on a ship". However later this expression formed the idiom - freeze the tail off a brass monkey which is nowadays used to describe extremely cold weather. The thing is that on ships, cannon balls were piled on deck in a pyramid shape and held in place by a ring called brass monkey. When the temperature dropped below a certain point, the brass ring would contract faster than the iron cannon balls, making the pyramid unstable and causing cannon balls to go rolling around (The Captain's Log, online resource). The idiom in the modern English language performs expressive function, illustrated by the following contexts:

But the weather was fit to freeze the tail off a brass monkey. Hence the haste of most of the players, when the final whistle blew, to take refuge within thefour jerry-built walls of the shack ... (Rouaud, 2011, p. 97)

January 26, 1913 Dearest Kiddo, 'Tis cold enough to freeze the tail off a brass monkey! Jack Frost has certainly paid many and quite long visits to us with the result that water in the water pitcher freezes! (Johnston, Means 2002, p. 223)

One more example in this category is the idiom shot across bows. During the $18^{\text {th }}$ century it meant "a shot that could be fired towards any ship whose 'colours' (nationality) had to be ascertained" (U.S. Coast Guard HITRON Jacsonville, online resource). However in modern English it gained another meaning "if you describe someone's actions as a shot across the bows of another person, you mean that it is a warning to that person to stop or change what they are doing" (Collins Dictionary, online resource). Thus, the initial meaning has been reconsidered and became an idiom, which now performs expressive function, see the following contexts:

A shot across the bows: home affairs under investigations for persistent breaches of FOI Act (The Mandarin, online resource).

Judge's shot across bows of judiciary (Bangkok Post, online resource).

Obama's shot across the bows over Syria. He goes on to say that it would not be 'a repetition of, you know, Iraq, which I know a lot of people are worried about - but if we are saying in a clear and decisive but very limited way, we send a shot across the bows, saying, stop doing this' (BBC News, online resource).

\section{Expansion of meaning}

The third transformation which calls for studying is expansion of meaning. In this case we are faced with the situation when the terms neither change meaning nor connotation, but come to denote a wider category of objects. Thus, a typical example in this category is sea dog, a term that historically meant a group of sea-raiders, (privateers, "Elizabethan Pirates"), who were authorized by Queen Elizabeth I of England, and also engaged in slave trading" [Rasor 2004, p. 247].
However, in modern English it denotes "a veteran sailor", thus the initial meaning has been expanded. Nevertheless this term is still used, performing both nominative and stylistic functions. To illustrate this the following extracts can be adduced:

Tattoos are big business. With celebrities dripping in them and their cool-value flying high, they're no longer the preserve of criminals and salty old sea dogs (Callan 2008, online resource).

This was the Tempest's husband and true love-and this-this was theold vagabond sea dog who lingered near town (McClure 2011, p. 174).

As it can be observed, in the adduced passages the slang term sea dog not only performs the nominative function meaning the old or experienced sailor, but also serves as a stylistic device, which adds expressiveness to the texts.

Another example to adduce in this category is the historical term argosy. Initially it was used by Shakespeare "to describe a fleet of merchant ships with treasures on the board" and "entered the English language as a corruption of 'Ragusa', whose vessels were commonly seen in the ports of northern Europe". In modern English its meaning has been expanded, and now the term stands for a rich supply or treasury of something, see the following contexts:

Literature-from classic novels to erotica to world folktales-is a vast, cheap, and virtually inexhaustible argosy of information about human nature (Gottchall, Wilson, p. 197).

Originating from a common ancestor, and sharing nearly $99 \%$ of our genes, chimps and bonobosrepresent an argosy of information about complex communication that is closely related to, but does not quite reach, human sophistication (Parrish 2013, p. 12).

From the following contexts it can be observed that not only meaning of the term has changed but also its connotation as well, as it has become more expressive and evaluative.As for the expansion of meaning now the term not only means concrete ships with treasures but any treasury possible.

One more example to introduce is the term to shanghai, which initially meant "to enroll or obtain (a sailor) for the crew of a ship by unscrupulous means, as by force or the use of liquor or drugs" (Dictionary.com, online resource). This verb joined English vocabulary in the 1850s, the era of so-called 'sailor thieves', as Shanghai was a common destination where the ships with abducted crews sailed. In modern English this meaning has expanded and now is to kidnap - not only sailors but other people as well, see the following context:

This is kind of cheesy and touristy, but also kind of fun and interesting if you don't put too much weight on detailed accuracy. Basically, there are anunderground series of tunnels beneath the city that were allegedly used to "Shanghai/kidnap" people (Casella 2016, online resource).

\section{Determinologisation}

Last process to mention in the current research is determinologisation - when the term loses its 
restricted terminological meaning and becomes part of the general vocabulary. Thus, this process affects only historical terms, such as the above-mentioned sheet anchor, argosy, blue Monday. One more example of this category is the term armada. Compare the initial meaning of this term with the new determinological one in the following contexts:

To accomplish the conquest of England, Felipe planned a two pronged attack. He would send his "Invincible Armada" of 125 ships into the English Channel where it would link up with the Duke of Parma in the Spanish Netherlands at Calais (Tudorplace, online resource).

UK economy grows used to the Spanish acquisitions when Spanish construction group Ferovial emerged last week as a potential bidder for BAA, the UK airport operator, the British press predictably labelled it part of a corporate Spanish armada raiding British assets (Financial Times, 2006).

From the passages adduced it can be seen that in the first text armada is definitely a term which plays a nominative function and is stylistically neutral, whereas in the second text it has non-terminological meaning which is at the same time expressive and associated with historical realia. Moreover it is metaphorically used to define something grand and seemingly invincible. Thus, it can be concluded that in case of determinologisation the terms: 1) become part of the general language; 2) are still associated with historical realia; 3 ) can gain additional expressiveness.

\section{Conslusion}

The research allowed to make several conclusion concerning the role historicisms play in modern English. Firstly, it has been proved that historicisms can make up active vocabulary by means of linguistic transformations that can result in change of meaning. In this case they can either save or loose touch with the historical background and play not only nominative but evaluative or expressive functions as well. Secondly, four common transformations have been singled out, i.e.: metaphorisation, idiomisation, expansion of meaning and determinologisation. Thirdly, having investigated different contexts where historicisms are used, it can be concluded that the connotation of historicisms can also change and become either ameliorative (sheet anchor) or pejorative (see admiral of the red, blue Monday).

Thus, it can be stated that historicisms frequently do not die out when the realia they denote disappear. Their meaning is reconsidered and transformed and it allows them to get a second life in the English language, adding to its expressivity.

\section{Factual materials}

Anchor Quotes - Anchor Quotes. Available at: http://www. brainyquote.com/topics/anchor-quotes.

Aust 2013 - Aust A. (2013) Modern Treaty Law and Practice. Cambridge: Cambridge University Press, 544 p. DOI: http://doi.org/10.1017/CBO9780511811517.
Bangkok Post - Bangkok Post, online resource.

BBC News - BBC News, online resource.

Brewer 1898 - Brewer E. (1898) Dictionary of Phrase and Fable. Available at: http://www.bartleby.com/81/3164. html.

Burnett 2012 - Burnett D. (2012) Blue Monday: a depressing day of pseudoscience and humiliation. The Guardian. Available at: http://www.theguardian.com/ science/blog/2012/jan/16/blue-monday-depressing-daypseudoscience.

Callan 2008 - Callan J. (2008) Tattoos: the Needle and the Damage Done. Indepenent UK. Available at: http://www. independent.co.uk/life-style/health-and-families/healthyliving/tattoos-the-needle-and-the-damage-done-793944. html.

Casella 2016 - Casella (2016), online resource.

Chavan 2019 - Chavan S. (2019) 11,100 last hope for bulls. SmartInvestor. Available at: http://smartinvestor.businessstandard.com.

Collins dictionary - Collins dictionary. Available at: http:// www.collinsdictionary.com.

Dickens 1980 - Dickens Ch. (1980) David Copperfield. London: Franklin Library, 803 p.

Dictionary.com - Dictionary.com, online resource.

Financial Times 2006 - Financial Times (2006). Available at: http://www.academia.edu/7039611/Economic conquistadors_conquer_new_worlds._Metaphor_ scenarios_in_English-language_newspaper_headlines_on Spanish_Foreign_Direct_Investment.

Foss, Saebi 2015 - Foss N.J., Saebi T. (2015) Business Model Innovation: The Organizational Dimension. Oxford: Oxford University Press, 308 p. Available at: http://b-ok.cc/ book/2946214/e5a800.

Gottschall 2005 - Gottschall J., Wilson D.S. (2005) The Literary Animal: Evolution and the Nature of Narrative. Northwestern University Press, 304 p. Available at: http:// bookre.org/reader?file $=658516$.

Johnston, Means 2002 - Johnston A.N., Means M.N. (2002) A Golden Glow in the East: Esther Nairn Nasmith's Letters from China, 1910 to 1925 . iUniverse, 2002. 440 p.

Lexico English dictionary - Lexico English dictionary. Available at: http://www.lexico.com/en/definition/nelson touch.

Marine Terms Dictionary - Marine Terms Dictionary. Available at: http://www.marineterms.com/termsdictionary/sea-words/cat-o-nine-tails.html.

McClure 2011 - McClure M.L. (2011) The Tide of the Mermaid Tears. Distractions Ink, 208 p.

Merriam-Webster Dictionary - Merriam-Webster Dictionary. Available at: http://www.merriam-webster. com.

Parrish 2013 - Parrish A. (2013) The (Instinctual) Art of Persuasion: A Brief Introduction to Adaptive Rhetoric. Available at: http://www.academia.edu/3787557/The Instinctual_Art_of_Persuasion.

Peat 2018 - Peat J. (2018) Man who coined the term 'Blue Monday' apologises for making January more depressing. Independent UK. Available at: http://www.independent. co.uk/news/uk/home-news/blue-monday-apologydepressing-january-misey-money-disposable-incomepsychology-dr-cliff-arnall-a8143246.html. 
Rouaud 2011 - Rouaud J. (2011) Simon and Schuster. Arcade, 999 p.

Simpson 1973 - Simpson J. (1973) The Routledge Dictionary of Historical Slang, $6^{\text {th }}$ Edition. Compiled by Eric Partridge. Routledge, 1066 p.

South China Morning Post 2019 - South China Morning Post (2019) No room to swing a cat: What life might look like in one of Hong Kong's new 177sqft flats. South China Morning Post. Available at: http://www.scmp.com/ article/1556719/no-room-swing-cat-what-life-might-look177sqft-flat.

Steffy 2013 - Steffy J.R. (2013) Illustrated Glossary of Ship and Boat Terms. The Oxford Handbook of Maritime Archaeology. Edited by Ben Ford, Donny L. Hamilton, and Alexis Catsambis. Oxford: Oxford University Press, 1150 p.

The Mandarin - The Mandarin, online resource.

The Captain's Log. Sailor Slang - The Captain's Log. Sailor Slang. Available at: http://blog.sailtrilogy.com/blog/ sailor-slang.

Tudorplace - Tudorplace. Available at: http://www. tudorplace.com.ar/Documents/defeat_of_the_armada.htm.

U.S. Coast Guard HITRON Jacsonville - U.S. Coast Guard HITRON Jacsonville, online resource.

Edneralova 2003 - Edneralova N.G. (2003) The outdated vocabulary of the Russian language of the newest period and its perception by the linguistic consciousness of modern schoolchildren: Ph.D. Thesis: specialty 10.02.01. Voronezh: Izd-vo Voronezhskogo gos. un-ta, 242 p. (in Russ.)

Kovaleva 1996 - Kovaleva E.V.(1996) Outdated vocabulary in the system of modern Russian language and in literary texts of the XIX century: abstract of Ph.D. dissertation. Moscow, 22 p. (In Russ.)

Konchakova 2008 - Konchakova E.V. (2008) Historical vocabulary as a means of creating a chronotope of fiction by A.S. Pushkin: Ph.D. Thesis: specialty 10.02.01. Voronezh: Izd-vo Voronezhskogo gos. un-ta, 283 p. (In Russ.)

Lazutova 2005 - Lazutova L.A. (2005) Functioning of historicisms of the Middle Ages in modern German: cognitive aspect: Ph.D. Thesis: 10.02.04. Saransk, 2005. (In Russ.)

Skryagin, Kalanov 2013 - Skryagin L.N. and Kalanov N.A. (2013) English-Russian dictionary of sea idioms and jargon. Moscow: Morkniga, 256 p. (In Russ.)

Khainzhamts 2007 - Khainzhamts O.E. (2007) Semantics and functions of obsolete words in the idiostyle of Yu.M. Nagibin: on the material of historical novels and short stories by Yu.M. Nagibin: Ph.D. Thesis: specialty 10.02.01. Moscow: izd-vo Gos. in-ta rus.yaz. im. A.S. Pushkina, 238 p. (In Russ.)

Chernysheva, Obnorsky, Krachkovsky 1965 Chernysheva V.I., Obnorsky S.P. and Krachkovsky I.Y. (Eds.) (1965) Dictionary of modern Russian literary language: in 17 vols. Moscow: Izdatel'stvo Akademii nauk SSSR, 36142 p. (In Russ.).

\section{References}

Rasor 2004 - Rasor E.L. (2004) English/British Naval History to 1815: A Guide to the Literature. Greenwood Publishing Group, 875 p. Available at: http://readli.net/ english-british-naval-history-to-1815-a-guide-to-theliterature.
White 2002 - White C. (2002) The Nelson Encyclopaedia. London: Chatham Publishing, Lionel Leventhal Limited, $236 \mathrm{p}$.

Brandes 2011 - Brandes M.P. (2011) Stylistic analysis: on the material of German language: 2nd edition, enlarged. Moscow: Librokom, 210 p. (In Russ.) Available at: http:// www.booksite.ru/fulltext/brandes/index.htm.

Koduhov 1979 - Koduhov V.I. (1979) Introduction to language studies. Moscow, 291 p. (In Russ.) Available at: http://dep_rya_i_mprya.pnzgu.ru/files/dep_rya_i_mprya. pnzgu.ru/koduhov__vvedenie_v_yazykoznanie.pd $\bar{f}$.

Kolesnik 1977 - Kolesnik G.S. (1977) On the issue of lexical historicisms in modern German language. Issues of German Philology, 1977, pp. 69-76. (In Russ.)

Kruglikova 2016 - Kruglikova E.A. (2016) Lexicology of the English language. Krasnoyarsk: Sib. feder. un-t, 163 p. (InRuss.)Availableat:http://obuchalka.org/20190729111929/ leksikologiya-angliiskogo-yazika-kruglikova-e-a-2016.html.

Teliya 1988 - Teliya V.N. (1988) Metaphorisation and its role in the creation of linguistic view of the world, in Serebennikov B.A., Kubryakova E.S., Postovalova V.I. et al. The role of the human factor in language: Language and view of the world. Moscow: Nauka (In Russ.) Available at: http://textarchive.ru/c-2963897-pall.html.

Shanskii 2013 - Shanskii N.M. (2013) Lexicology of the modern Russian language. Moscow: Librokom, 312 p. (In Russ.)

\section{Библиографический список}

Rasor 2004 - Rasor E.L. English / British Naval History to 1815: A Guide to the Literature. Greenwood Publishing Group, 2004. 875 p. URL: http://readli.net/english-britishnaval-history-to-1815-a-guide-to-the-literature.

White 2002 - White C. The Nelson Encyclopaedia. London: Chatham Publishing, Lionel Leventhal Limited, 2002. 236 p.

Брандес 2011 - Брандес М.П. Стилистический анализ (на материале немецкого языка). Изд. 2-е, доп. Москва: Либроком, 2011. 210 c. URL: http://www.booksite.ru/ fulltext/brandes/index.htm.

Кодухов 1979 - Кодухов В.И. Введение в языкознание. Москва, 1979. 291 c. URL: http://dep_rya_i_mprya. pnzgu.ru/files/dep_rya_i_mprya.pnzgu.ru/kodūhov_ vvedenie_v_yazykoznanie. $\bar{p}$ df.

Колесник 1977 - Колесник Г.С. К проблеме лексических историзмов в современном немецком языке // Вопросы германской филологии. Калинин: Калининский гос. ун-т, 1977. С. 69-76.

Кругликова 2016 - Кругликова Е.A. Лексикология английского языка. Красноярск: Сиб. федер. ун-т, 2016. 163 c. URL: http://obuchalka.org/20190729111929/ leksikologiya-angliiskogo-yazika-kruglikova-e-a-2016. html.

Телия 1988 - Телия В.Н. Метафоризация и ее роль в создании языковой картины мира // Роль человеческого фактора в языке: Язык и картина мира / Б.А. Серебенников, Е.С. Кубрякова, В.И. Постовалова [и др.]. Москва: Наука, 1988. URL: http://textarchive.ru/c-2963897-pall. html.

Шанский 2013 - Шанский Н.M. Лексикология современного русского языка. Москва: Либроком, 2013. $312 \mathrm{c}$. 